E-ISSN: $2502-6674$

P-ISSN: 2502-6666

http://ojs.uho.ac.id/index.php/p_sejarah_uho

\title{
SEJARAH BANDARA MATAHORA DI PULAU WANGI-WANGI KABUPATEN WAKATOBI (2007-2017) ${ }^{1}$
}

\section{HISTORY OF MATAHORA AIRPORT IN WANGI-WANGI ISLAND, WAKATOBI DISTRICT (2007-2017) ${ }^{1}$}

\author{
Asmiani $^{2}$ \\ e-mail: asmiani88@gmail.com \\ Hayari $^{3}$ \\ e-mail: hayari@uho.ac.id
}

\section{${ }^{1)}$ Hasil Penelitian Tahun 2018, ${ }^{2)}$ Alumni Jurusan Pendidikan Sejarah, ${ }^{3)}$ Dosen FKIP UHO}

ABSTRAK: Permasalahan pokok dalam penelitian ini adalah: (1) Apa latar belakang pembangunan Bandara Matahora di Pulau Wangi-Wangi Kabupaten Wakatobi, (2) Apa kendala yang dihadapi dalam pembangunan Bandara Matahora di Pulau Wangi-Wangi Kabupaten Wakatobi? (3) Apa dampak yang ditimbulkan terhadap pembangunan Bandara Matahora di Pulau Wangi-Wangi Kabupaten Wakatobi? dan (4) Bagaimana Perkembangan pembangunan Bandara Matahora di Pulau Wangi-Wangi Kabupaten Wakatobi? Penelitian ini menggunakan metode sejarah yang dikemukakan oleh Helius Sjamsuddin, yang terdiri atas 3 tahap yaitu: (1) Heuristik yakni mencari sumber melalui wawancara, studi kepustakaan, dan penelitian lapangan, (2) Kritik Sumber terdiri atas kritik eksternal dan kritik internal guna mendapat data yang akurat, (3) Historiografi yang dimaksudkan dalam bentuk karya tulis kronologis, sistematis dan ilmiah. Penelitian ini menunjukan bahwa latar belakang perkembangan Bandara Matahora berawal dari pemikiran atau ide bupati wakatobi Ir. Hugua yang yang tergambar dalam visi misinya membangun dan menjadikan Kabupaten Wakatobi menjadi daerah yang digemari oleh banyak orang dengan visi "Terwujudnya Surga Nyta Bawah Laut di Pusat Segitiga Karang Dunia" (2) Kendala yang dihadapi dalam pembangunan Bandara Matahora dapat dilihat dari pandangan masyarakat yang diwujudkan dalam bentuk respon dari masyarakat berkaitan dengan pembangunan Bandara Matahora serta kecenderungan rencana yang dilakukan pasca Bandara terbangun. Respon yang dimaksud adalah respon mengenai pembangunan Bandara Matahora. Misalnya dari satu pihak menerima adanya Bandara Matahora dipihak lain ada yang menolak pembangunan Bandara Matahora. (3) Dampak dari pembangunan Bandara Matahora ialah terdapat dampak yang bersifat positif dan yang bersifat negatif bagi masyarakat dan daerah. (4) Perkembangan pembangunan Bandara Matahora dari tahun ke tahun semakin bagus, dimana Bandara yang menjadi kebanggaan masyarakat tersebut digunakan dengan semaksimal mungkin dan pembangunan tambahan Bandara terus berkelanjutan hingga saat ini. Disamping itu, banyak wisatawan dalam dan luar negeri yang menggunakan Bandara Matahora tersebut sebagai alternatif yang memungkinkan perjalanan masyarakat bisa dijangkau dengan cepat.

\section{Kata Kunci: Sejarah, Bandara Matahora, Pulau Wangi-Wangi, dan Wakatobi}

ABSTRACT: The main problems in this study are: (1) What is the background of the development of Matahora Airport on Wangi-Wangi Island, Wakatobi Regency, (2) What are the obstacles faced in the construction of Matahora Airport on Wangi-Wangi Island, Wakatobi Regency? (3) What are the impacts on the construction of Matahora Airport on Wangi-Wangi Island, Wakatobi Regency? and (4) How is the development of Matahora Airport development on Wangi-Wangi Island, Wakatobi Regency? This research uses the historical method proposed by Helius Sjamsuddin, which consists of 3 stages, namely: (1) Heuristics which is looking for sources through interviews, library research, and field research, (2) Source Criticism consists of external criticism and internal criticism in order to obtain data accurate, (3) Historiography intended in the form of chronological, systematic and scientific writing. This research shows that the background of the 
E-ISSN: $2502-6674$

P-ISSN: 2502-6666

http://ojs.uho.ac.id/index.php/p_sejarah_uho

development of Matahora Airport originated from the thoughts or ideas of the Regent of Wakatobi, Ir. Hugua, who is depicted in his vision and mission to build and make Wakatobi Regency a favorite area for many people with the vision of "Realizing the Underwater Paradise of the Sea at the Center of the World Coral Triangle" (2) Constraints faced in the construction of Matahora Airport can be seen from the view of the community that is realized in the form of response from the public relating to the construction of Matahora Airport and the tendency of plans to be carried out after the Airport was built. The response in question is the response regarding the construction of Matahora Airport. For example, from one party accepting the existence of Matahora Airport, on the other hand there are those who reject the construction of Matahora Airport. (3) The impact of Matahora Airport development is that there are positive and negative impacts on the community and the region. (4) The development of the Matahora Airport development from year to year is getting better, where the Airport which is the pride of the community is used to the maximum extent possible and the construction of additional airports continues to the present. In addition, many domestic and foreign tourists who use the Matahora Airport as an alternative that allows people's trips can be reached quickly.

\section{Keywords: History, Matahora Airport, Wangi-Wangi Island, and Wakatobi}

\section{PENDAHULUAN}

Secara etimologi kata sejarah diambil dari bahasa melayu dari kata Arab "Sadjarah" artinya pohon kayu. Kemudian diartikan keturunan da nasal-usul lebih kemudian lagi artinya disamakan lagi dengan silsilah, riwayat, tarik, hikayat tambo, babat dan sebagainya. Misalnya sejarah melayu, hikayat raja-raja Pasai, tarik Nabi, Babat Tanah Jawi, dam lain-lain. Dimasa kebangkitan nasional/pergerakan kebangsaan belum ada kesatuan dalam pemakaian terminology atau peristilahan. Nanti disaat masa Jepang dan sesudahnya baru kemudian kata sejarah menjadi istilah umum yang sama artinya dengan Historia (Maelissas, 2007: 63).

Historia berasal dari bahasa Yunani yaitu dari kata istirio. Jan Romein mengartikan bahwa istirio adalah pengetahuan yang di dapat dengan cara mendengar dan melihat. Historia dalam bahasa Yunani berarti saya menyelidiki dan mencari (I Seacrh Into). Yang pertama-tama disebut Historia itu adalah hasil karya Herodotus. Herodotus sendiri tidak memakai istilah Historia melainkan istilah yang sama artinya yang sama dengan penyelidikan. Tetapi orang Yunani yang kemudian membaca karya Herodotus itu menyebutkannya Historia. Herodotus yang suka berkelana karena ingin mengetahui tentang negara-negara dan mau mengumpulkan fakta-fakta berdasarkan apa yang didengar atau dilihatnya. Buku atau cacatan itu kemudian dibaca oleh orang-orang Yunani. Kemudian karya orang Yunani semacam itu disebut Historia dan istilah ini digunakan sampai sekarang. Karena itu Herodotus disebut sebagai Bapak Sejarah (Maelissas, 2007: 63). Sehubungan dengan pengertian tersebut Kartodirdjo (2002: 67) membagi sejarah menjadi dua yaitu sejarah dalam arti objektif yang merupakan kejadian atau peristiwa sejarah yang tidak dapat terulang lagi, dan sejarah dalam arti subjektif atau suatu kontruksi (bangunan) yang disusun oleh penulis sebagai suatu uraian cerita (kisah). Kisah tersebut merupakan suatu kesatuan rangkaian dari fakta-fakta yang saling berkaitan.

Sistem transportasi udara di Indonesia semakin berperan dalam perkembangan perekonomian dan merupakan kewenangan transportasi udara untuk dapat melayani seluruh wilayah nusantara terutama dalam kaitannya dengan percepatan arus informasi, barang, penumpang dan lain sebagainya. Bandar udara yang selanjutnya disingkat bandara merupakan prasarana pendukung transportasi udara yang sangat penting karena daerah-daerah yang sebelumnya sudah dijangkau melalui jalur transportasi darat kini dapat diatasi melalui jalur transportasi udara untuk berhubungan dalam bidang ekonomi, pemerintahan, pariwisata dan lainlain. Bandar Udara atau Bandara yang juga populer disebut dengan istilah airport merupakan sebuah fasilitas dimana pesawat terbang seperti pesawat udara dan helikopter dapat lepas landas dan mendarat. Suatu bandar udara yang paling sederhana minimal memiliki sebuah landasan pacu atau helipad (untuk pendaratan helikopter), sedangkan bandara-bandara besar biasanya dilengkapi 
E-ISSN: $2502-6674$

P-ISSN: 2502-6666

http://ojs.uho.ac.id/index.php/p_sejarah_uho

berbagai fasilitas lain, baik untuk operator layanan penerbangan maupun bagi penggunanya seperti bangunan terminal dan hanggar.

Pembangunan diharapkan dapat meningkatkan pembangunan ekonomi masyarakat di wilayah sekitarnya, dan meningkatkan kesejahteraan masyarakat. Menurut Coralie Briyant dan Louise White dalam Widjaya, (1982: 14) bahwa pembangunan merupakan upaya untuk meningkatkan kemampuan manusia untuk mempengaruhi masa depannya. Kamarsyah (1996: 124) mengemukakan bahwa pada hakikatnya pembangunan adalah pembangunan manusia seutuhnya dan pembangunan seluruh masyarakat, ini berarti bahwa pembangunan mencakup: pertama, kecukupan dan kemajuan lahiriah, seperti pangan, sandang dan papan, pendapatan yang layak dan sebagainya. Kedua ketentraman beragama dan sebagainya. Ketiga, kemajuan meliputi seluruh pembangunan

Kabupaten Wakatobi merupakan wilayah yang san gat strategis, karena merupakan jantung segi tiga karang dunia dengan sektor andalan (leading sector) perikanan, kelautan dan pariwisata, maka pemerintah Kabupaten Wakatobi terus bergerak membenahi infrastruktur dibidang perhubungan khususnya perhubungan udara (Hadara, 2017: 221). Pembangunan Bandara Matahora berawal dari pemikiran seorang pemimpin bernama Ir. Hugua yang merupakan Bupati Wakatobi, yang dalam visi misinya ingin membangun dan menjadikan Kabupaten Wakatobi menjadi daerah yang digemari oleh banyak orang di dunia dengan visi "Terwujudnya Surga Nyata Bawah Laut di Pusat Segitiga Karang Dunia", yang kemudian visi tersebut dilengkapi dengan misi sebagai berikut: (1). Medorong peningkatan dan pemerataan kesejahteraan masyarakat, (2). Meningkatkan pengelolaan dan pelestarian sumberdaya alam, (3). Meningkatkan kualitas dan daya dukung infrastruktur wilayah, (4). Meningkatkan kualitas pelayanan publik dan tata kelola pemerintahan, dan (5). Mengembangkan situasi yang kondusif bagi kehidupan masyarakat yang inofatif.

Atas dasar Visi dan Misi itulah sehingga Ir. Hugua mengatakan alasan dibangunnya Bandara Matahora salah satunya ialah bisa menghubungkan Kabupaten Wakatobi dengan dunia luar dan membuka mata Internasional bahwa Kabupaten Wakatobi adalah kawasan yang memiliki keanekaragaman hayati bahari terbesar di dunia. Masyarakat yang terkena dampak langsung pemabungan Bandara Matahora yang sebagian besar petani, dimana setelah dibangunnya Bandara Matahora ada respon mayarakat mengenai keberadaan pembangunan Bandara Matahora. Respon tersebut ada yang berupa positif dan negatif. Respon positif yang dimaksud adalah masyarakat mendukung dengan dibangunnya Bandara Matahora tersebut. Masyarakat yang setuju akan dibangunnya Bandara Matahora mereka beranggapan bahwa dengan adanya Bandara Matahora maka kegiatan perekonomian akan tumbuh dan berdampak langsung terhadap pendapatan masyarakat. Dengan adanya pembangunan Bandara tersebut nantinya akan dapat mebuka lapangan kerja baru bagi masyarakat sekitar. Pembangunan tersebut akan merubah pembangunan daerah yang tadinya hanya merupakan satu pedesaan kemudian akan berubah menjadi sebuah perkotaan yang cukup ramai. Sementara respon negatif dari masyarakat apabila dibangunnya Bandara Matahora adalah tanah adat akan dijual dan akan merugikan daerah. Kehadiran bandar udara di sebuah kota, banyak akan mempengaruhi perkembangan kota tersebut.

\section{METODE PENELITIAN}

Penelitian ini dilakukan di Desa Matahora Kecamatan Wangi-Wangi dengan jenis penelitian sejarah yang bersifat deskriptif kualitatif yakni penulis memberikan gambaran secara jelas tentang latar belakang sejarah Bandara Matahora di Pulau Wangi-Wangi Kabupaten Wakatobi, proses perkembangan Bandara Matahora di Pulau Wangi-Wangi Kabupaten Wakatobi, serta kendala yang dihadapi dalam proses pembangunan Bandara Matahora di Pulau Wangi-Wangi Kabupaten Wakatobi, proses perkembangan Bandara Matahora di Pulau Wangi-Wangi Kabupaten Wakatobi serta kendala yang dihadapi dalam proses pembangunan Bandara Matahora di Pulau Wangi-Wangi Kabupaten Wakatobi, proses perkembangan Bandara Matahora di Pulau WangiWangi Kabupaten Wakatobi.

Pendekatan yang digunakan dalam penelitian ini adalah pendekatan strukturis seperti yang dikemukakan oleh Leirissa (1996: 12), bahwa terdapat tiga domain dalam penelitian sejarah yaitu domain peristiwa, domain struktur dan domain strukturis. Adapun sumber data yang digunakan 
E-ISSN: $2502-6674$

P-ISSN: 2502-6666

http://ojs.uho.ac.id/index.php/p_sejarah_uho

dalam penelitian ini adalah: sumber tertulis, sumber lisan, dan sumber visual. Teknik pengumpulan sumber data yang akan digunakan peneliti mengacu pada pendapat Sjamsuddin, (2007: 17-239) bahwa pengumpulan sumber (heuristik) yang dilakukan dengan cara: penelitian lapangan yang terdiri dari wawancara, dan pengamatan, penelitian kepustakaan, kritik sumber yang terdiri dari kritik eksternal dan krtik internal, historiografi yang terdiri dari penasfiran, penjelqasan dan penyajian.

\section{HASIL PENELITIAN DAN PEMBAHASAN Latar Belakang Pembangunan Bandara Matahora di Pulau Wangi-Wangi Kabupaten Wakatobi}

Bandar Udara Matahora adalah bandar udara yang terletak di Pulau Wangi-Wangi Kabupaten Wakatobi Sulawesi Tenggara. Bandar Udara ini memiliki ukuran landasan pacu $2.000 \mathrm{x}$ $30 \mathrm{~m}$. Sehingga menjadi 13/31 berukuran 2.450 by 45 meter $(8.038 \times 148 \mathrm{ft})$. Jarak dari WangiWangi sebagai ibu kota Kabupaten Wakatobi yakni sekitar $17 \mathrm{~km}$. Rencana pembangunan bandara yang ada di PulauWangi-Wangi Sulawesi Tenggara merupakan pembangunan yang cukup besar menggunakan anggaran di Kabupaten Wakatobi.

Pembangunan Bandara Matahora berawal dari pemikiran seorang pemimpin bernama Ir. Hugua yang merupakan Bupati Wakatobi periode 2006-2011, dalam visi misinya ingin membangun dan menjadikan Kabupaten Wakatobi menjadi daerah yang digemari oleh banyak orang dengan visi "Terwujudnya Surga Nyta Bawah Laut di Pusat Segitiga Karang Dunia". Apabila dipilah dan diartikan satu persatu adalah sebagai berikjut "Surga nyata" adalah perwujudan kesejahteraan dan kemakmuran masyarakat, "Bawah laut" adalah wujud dari pemanfaatan dan kelestarian lingkungan atas potensi sumber daya laut, "Pusat Segi Tiga Karang Dunia"merupakan aktualisasi posisi geografis Kabupaten Wakatobi sebagai pusat segi tiga karang dunia yang memiliki keanekaragaman hayati tertinggi di dunia. Yang kemudian visi tersebut dilengkapi dengan misi sebagai berikut: (1). Medorong peningkatan dan pemerataan kesejahteraan masyarakat, (2). Meningkatkan pengelolaan dan pelestarian sumberdaya alam, (3). Meningkatkan kualitas dan daya dukung infrastruktur wilayah, (4). Meningkatkan kualitas pelayanan publik dan tata kelola pemerintahan, dan (5). Mengembangkan situasi yang kondusif bagi kehidupan masyarakat yang inofatif.

Atas dasar Visi dan misi itulah sehingga Ir. Hugua mengatakan alasan dibangunnya Bandara Matahora salah satunya ialah bisa menghubungkan Kabupaten Wakatobi dengan dunia luar dan membuka mata Internasional bahwa Kabupaten Wakatobi adalah kawasan yang memiliki keanekaragaman hayati bahari terbesar di dunia. Setelah pelantikan yang tertunda selama sembilan bulan sepuluh hari, akhirnya 28 Juni 2006 di Wangi-Wangi Gubernur Sulawesi Tenggara Ali Mazi meneguhkan Hugua menjadi bupati Wakatobi periode 2006-2011. Tepuk tangan menggemuruh dari para pegawai dan masyarakat yang memenuhi gedung wanita Wangi-Wangi. Mereka menyaksikan lahirnya pemimpin baru mereka di seantero Wakaobi. Sebuah kepulauan yang begitu lama tak terurus.

Usai penobatannya, Hugua langsung mengajak Gubernur Ali Mazi keluar meninggalkan orang-orang yang masih asyik bercengkrama di ruangan. Meski setengah meragukan ide Hugua, Ali Mazi tetap mengikuti langkah kaki Hugua keluar menuju parkir mobil. Orang-orang digedung wanitapun kebingunan melihat Bupati Wakatobi dan Gubernur Sulawesi Tenggara keluar ruangan, yang ternyata tidak menuju rumah jabatan (Arman, 2016: 2).

Dalam setiap pembangunan, tentu saja diharapkan dapat berdampak positif bagi masyarakat, namun tidak dapat dipungkiri dengan adanya pembangunan tersebut juga mungkin akan menimbulkan dampak negatif bagi beberapa pihak tertentu. Oleh karena itu, suatu pembangunan tersebut harus direncanakan dengan baik sehingga mendapatkan hasil yang maksimal dan dapat meminimalisir dampak negatif yang mungkin saja berasal dari beberapa pihak tertentu yang tidak mendukung pembangunan tersebut.

Pada tahun 2006 Ir. Hugua selaku Bupati Wakatobi berangkat ke Jakarta untuk menghadap ke Kementrian perhubungan bagian kebandaraudaraan. Kala itu, membuat beberapa pejabat direktorat kebandarudaraan Kementrian Perhubungan langsung melakukan rapat. Sebab saat itu 
E-ISSN: $2502-6674$

P-ISSN: 2502-6666

http://ojs.uho.ac.id/index.php/p_sejarah_uho

belum ada kebijakan pembangunan bandara di daerah karena derap otonomi daerah baru saja dimulai. Ir. Hugua bolak-balik Jakarta untuk meyakinkan Kementrian Perhubungan akan dibangunnya Bandara di Wakatobi. Setelah keluar surat izin yang tertera dalam beleid Keputusan Kementrian Perhubungan No. 13/2007 yang isinya antara lain adalah pembangunan bandara di Wakatobi Sulawesi Tenggara boleh menggunakan dana daerah (APBD) melalui UPTD (Dinas Perhubungan).

Setelah itu, pengkajian survei lokasi kemudian dimulai. Tim survei pertama dari Kementrian Perhubungan. Mereka datang dari Jakarta menuju Kendari, yang ditempuh tiga jam dengan pesawat. Dari Kendari mereka melanjutkan perjalanan ke Wangi-Wangi, ibu kota Kabupaten Wakatobi, dengan mengendarai kapal sewaan yang kecepatannya 5-15 knot, yang perjalanannya ditempuh kurang lebih 12 jam, dengan tinggi ombak lebih kurang 5 meter. Dengan itu, nyaris semua rombongan tim Kementrian Perhubungan itu mengalami mabuk laut, bahkan ada yang pingsan di kapal dikarenakan tak kuat dengan guncangan ombak besar. Kemudian, tim survei kedua adalah dari DPR RI. Tim mereka juga mengalami mabuk laut karena hantaman ombak dasyat. Gulungan ombak lautnya seringkali memakan korban (Arman, 2016: 38). Pembangunan Bandara Matahora lokasi yang digunakan adalah tanah yang dibeli pada masyarakat yang harganya saat itu senilai 3000 rupiah/meter. Akhirnya, kedua tim itu merasakan bagaimana sulitnya kehidupan masyarakat Wakatobi selama ini, dan mengerti isi kepala sang Bupati, mengapa ia begitu keras memperjuangkan hadirnya pembangunan bandara di daerahnya. Dengan jangka waktu setahun pembangunan Bandara dengan landasan pacu tahap pertama dengan panjang 1400 meter teraspal dan siap didarati pesawat berjnis fokker (Arman, 2016: 42).

Pembangunan Bandara Matahora begitu penting bagi masyarakat Wakatobi khususnya dan penting bagi daerah hingga bagi Negara Kesatuan Republik Indonesia karena Wakatobi merupakan daerah strategis yang memiliki banyak kekayaan alam dan kekayaan hayati di dalam laut dalam hal ini Wakatobi merupakan daerah jantung segitiga karang dunia yang merupakan daerah incaran wisatawan sebagai tempat wisata, disamping itu Kabupaten Wakatobi memiliki banyak budaya dan tradisi baik tradisi lisan, tarian hingga daerah yang memiliki situs sejarah yang begitu banyak.

\section{Kendala dalam Pembangunan Bandara Matahora di Kabupaten Wakatobi}

Rencana pembangunan Bandara yang ada di Pulau Wangi-Wangi Kabupaten Wakatobi Sulawesi Tenggara merupakan pembangunan yang cukup besar di Kabupaten Wakatobi dan memerlukan dana yang sangat besar. Namun adanya rencana pembangunan Bandara ternyata tidak langsung disetujui oleh semua pihak masyarakat yang ada di Pulau Wangi-Wangi. Dalam proses pelaksanaannya ada penolakan dari pihak masyarakat yang akan terkena dampak langsung pembangunan Bandara Matahora. Masyarakat yang terkena dampak langsung pembangunan Bandara yang sebagian besar petani beranggapan bahwa apabila pembangunan Bandara terlaksana maka mata pencaharian mereka akan hilang.

Kendala dan perkembangan Bandara Matahora dapat dilihat dari pandangan masyarakat yang diwujudkan dalam bentuk respon dari masyarakat berkaitan dengan pembangunan Bandara Matahora serta kecenderungan rencana yang akan dilakukan pasca Bandara terbangun. Respon yang dimaksud adalah respon mengenai pembangunan Bandara Matahora. Misalnya dari satu pihak menerima adanya Bandara matahora dipihak lain ada yang menolak pembangunan Bandara Matahora.

Setelah tersebarnya kabar akan dibangunnya Bandara Matahora yang dimana menggunakan uang daerah (APBD), maka ratusan lapisan masyarakat turun ke jalan, juga menduduki kantor bupati, rumah jabatan, dan area proyek pembangunan Bandara. Mereka berteriak, memaki, dan mengancam Hugua jika tetap berani melanjutkan pembangunan Bandara. Hampir 95 persen masyarakat dan semua anggota parlemen Wakatobi menolak gagasan pembangunan Bandara itu disebabkan ketidak mampuan mereka dan ketidak sepahaman mereka dengan alur pemikiran sang Bupati.

Area Bandara pun dipalang dengan tulisan dengan bernada ancaman "Siapa yang Berani Membangun Bandara di Atas Tanah Warisan Nenek Moyang Kami Ini, Nyawa Kalian Akan Melayang" (Arman, 2016: 38). Kamaludin mengatakan bahwa, banyak masyarakat yang datang ke 
E-ISSN: $2502-6674$

P-ISSN: 2502-6666

http://ojs.uho.ac.id/index.php/p_sejarah_uho

lokasi pembangunan Bandara Matahora untuk memboykot pembangunan tersebut, mereka menanam kelapa di lokasi pembangunan sebagai tanda tanah itu tidak di ijinkan untuk dilakukannya pembangunan. Demo itu terjadi berhari-hari, siang dan malam. Ancaman mereka juga tidak main-main. Sebab mereka datang tidak dengan tangan kosong, mereka datang dengan membawa parang panjang dan tombak. Ancaman mereka tidak main-main sehingga membuat mandor pembangunan Bandara itu ciut dan menyatakan mundur dari pekerjaannya. Mendengar hal tersebut Ir. Hugua meminta bantuan kepolisian untuk mengamankan area Bandara yang sedang dalam proses penggarapan landasan pacu, tetapi meski polisi sudah turun tangan mengamankan, tetap saja tidak bisa membendung ratusan masyarakat yang demo di area Bandara dan Kantor

Semua anggota DPRD Wakatobi pun menolak gagasan pembangunan Bandara Matahora itu. Mereka beranggapan bahwa membangun Bandara di daerah khususnya di daerah terpencil, umumnya karena ada perusahaan asing yang sedang mengelola sumber daya alam yang dimiliki oleh daerah tersebut. Semntara apa yang dimiliki Wakatobi? Wakatobi tidak menyimpan kekayaan yang bias menarik para investor atau pemerintah untuk membangun infrastruktur Bandara. Tanahnya kering dan berkarang, tidak bias ditumbuhi tanaman kecuali tanaman ubi kayu dan jagung. Kedua tanaman itupun belum tentu bias hidup bila tidak ada kebaikan langit menurunkan hujan (Arman, 2016: 14).

Karena beberapa alasan itu masyarakat dan Anggota DPRD Wakatobi menolak rencana pembangunan Bandara. Disamping itu, hal yang sama diungkapkan oleh Wa Mbunga bahwa dalam pembangunan Bandara Matahora di Kabupaten Wakatobi masyarakat dan anggota DPRD Wakatobi menolak rencana pembangunan Bandara. Setiap hari kantor bupati dan rumah jabatannya ditongkrongi ratusan masyarakatnya. Laki-laki dan perempuan, dewasa dan anak-anak. Mereka berdemo, berteriak, memaki Hugua dan sebutan "BUPATI GILA" serta mereka juga menghunuskan langkah untuk menghentikan langkah Hugua.

Setelah menghadapi 184 kali demostrasi dari masyarakat, dua tahun menjadi bupati "Buronan" masyarakat, dengan mendapat gelar "Bupari Gila" dari masyarakat dan pejabat daerah tidak menyetujui, meski jabatan dan nyawa terancam, melewati perjalanan panjang yang berlikuliku untuk meyakinkan pemerintah pusat agar dibangunnya Bandara di daerahnya. Sekilah Ir. Hugua tampak otoriter, memaksakan keputusannya tanpa menghiraukan suara rakyatnya, namun jauh di balik keputusannya itu, iya punya alasan sendiri hingga akhirnya Kabupaten Maritim (Kabupaten Wakatobi) memiliki bandara perintisyang dinamakan Bandara Matahora (Arman, 2016: 17).

Setelah Bandara siap untuk diresmikan, ditengah malam hari terjai serangan yang tak terduga dari masyarakat yang kontra pada pembangunan Bandara. Sebuah mobil Pick up meneobos ke Bandara dengan mengangkut batu-batu besar dan puluhan batang pohon kelapa. Salah satu dari mereka memberikan intruksi. Perang dimulai, aksi boikot sedang dijalankan. Batu-batu besar diletakan ditengah landasan pesawat sebagian lagi menggotong pohon-pohon kelapa dan menanam ratusan pohon-pohon kelapa tersebut di sepanjang jalan yang belum teraslpal.

Disudut lain, sekumpulan orang menutup akses jalan menuju Bandara. Jalanan dari kota Wangi-Wangi mereka blokir dengan meletakan bebatuan besar dan melintangkan batang pohon agar kendaraan tidak bias melintas menuju Bandara. Aksi boikot tengah mala mini segera dilaporkan kepada Kepala Desa Matahora yang kemudian dilanjutkan kepada Hugua tengah malam itu juga. Setelah mendengar kabar itu, Ir. Hugua pun langsung menghambur keluar dan tak lupa menelpon Kapolres untuk menuju lokasi Bandara. Jarum jam menunjuk pukul satu dini hari ketika mereka sampai di lokasi Bandara. Kapolrespun menginstruksikan agar pohon-pohon kelapa itu dicabut. Terhitung 156 pohon yang telah tertanam malam itu, dan beberapa jam kemudian dicabut. Tepat pukul empat pagi lokasi Bandara itu bersih kembali.

\section{Dampak Terhadap Pembangunan Bandara Matahora di Pulau Wangi-Wangi Kabupaten Wakatobi}

Dengan kian berkembangnya dunia penerbangan, keberadaan Bandar udara (Bandara) sebagai terminal terbang dan mendaratnya pesawat menjadi sangat strategis. Tidak heran jika di berbagai Negara, termasuk Indonesia pembangunan Bandara terus digiatkan. Bahkan, di Kabupaten 
E-ISSN: $2502-6674$

P-ISSN: 2502-6666

http://ojs.uho.ac.id/index.php/p_sejarah_uho

Wakatobi. Meski dalam pembangunan Bandara Matahora tersebut penuh tantangan yang berlikuliku hingga akhirnya berhasil terbangun sebuah Bandara Matahora bias menunjang perekonomian di Kabupaten Wakatobi. Namun, selain manfaatnya yang banyak, keberadaan Bandara juga kiat dirasakan menjadi masalah bahkan menggangu sebagian masyarakat, terutama yang tinggal di bagian lokasi Bandara.

Dampak terhadap pembangunan Bandara Matahora di Pulau Wangi-Wangi Kabupaten Wakatobi dapat dilihat dari dampak positif dan dampak negatif sebagai berikut:

1. Dampak Positif

Dampak positif terhadap pembangunan Bandara Matahora di Pulau Wangi-Wangi Kabupaten Wakatobi diantaranya adalah sebagai berikut:

a. Terbukanya lapangan kerja bagi masyarakat yang tidak atau yang sedang menganggur di wilayah sekitaran Bandara Matahora terhusus adalah masyarakat yang ada di Desa Sousu

b. Banyaknya wiasatawan yang masuk ke Wakatobi baik dalam maupun luar negeri

c. Pertumbuhan ekonomi masyarakat yang ada di Wakatobi khususnya di Pulau Wangi-Wangi membaik

d. Bertambahnya SDM Wakatobi

e. Mempermudah akses transportasi lintas daerah

f. Mendapat penghargaan sebagai Bandara terbaik (The Best Airport Award)

g. Menjadi tuan rumah penyelenggaraan Konferensi Internasional UCLG (United Cities Local Government Asia Pasifik)

2. Dampak Negatif

Dampak negatif terhadap pembangunan Bandara Matahora di Pulau Wangi-Wangi Kabupaten Wakatobi diantaranya adalah sebagai berikut:

a. Lahan pertanian warga sekitar Bandara Matahora berkurang

b. Aspek keselamatan bagi warga yang tinggal di sekitar Bandara Matahora

c. Bisa menimbulkan polusi dan kebisingan bagi masyarakat yang tinggal di sekitar daerah Bandara Matahora

d. Mengurangi pendapatan pengusaha transportasi laut terutama transportasi kecil yang dimiliki masyarakat lockal

e. Terjadi transisi budaya masyarakat akibat bertambahnya pengunjung yang membawa budaya berbeda dengan budaya yang ada.

\section{Perkembangan Bandara Matahora dari Tahun 2007-2017}

Perkembangan Bandara Matahora dari tahun ke tahun semakin bagus, dimana Bandara yang menjadi kebanggaan masyarakat tersebut digunakan dengan semaksimal mungkin dan pembangunan tambahan Bandara terus berkelanjutan hingga saat ini. Disamping itu, banyak wisatawan dalam dan luar negeri yang mengunakan Bandara Matahora tersebut sebagai alternatif yang memungkinkan perjalanan masyarakat bisa di jangkau dengan cepat.

Dalam perkembangannya Pemda pun terus mengupayakan pembangunan Bandara Matahora berhenti sampai pada landasan pacu tahap pertama dengan panjang 1400 meter teraspal dan siap didarati pesawat berjnis fokker. Hugua melakukan lobi ke DPR RI untuk pembangunan landasan pacu tahap dua yaitu 2000 meter dengan biaya APBN. Dan lobi Hugua itupun berhasil (Arman, 2016: 45).

Tercatat di tahun 2012, pembangunan Bandara Matahora tahap dua dilanjutkan dengan penambahan pelapisan overlay 1000 × 30 meter. Kali ini taka da lagi masyarakat yang melakukan demontrasi. Mereka akhirnya merasakan manfaat dari kehadiran Bandara Matahora yang telah mengubah gerak aktivitas masyarakat Wakatobi dan juga mengubah gerak hidup dalam diri setiap penduduknya.

Sejak tahun 2012, Wakatobi telah memiliki Bandar Udara dengan panjang landasan 2.500 meter dengan rincian runway 2.000 meter serta uprond $103 \times 73$ meter, dilengkapi terminal penumpang. Bandara yang kelahirannya memiliki cerita yang berkelok-kelok ini resmi terdaftar di Kementrian Perhubungan sebagai salah satu Bandara di Indonesia. Karena jumlah penumpang terus 
E-ISSN: $2502-6674$

P-ISSN: 2502-6666

http://ojs.uho.ac.id/index.php/p_sejarah_uho menambah, maskapainya pun berganti Lion Air (Wings Air) yang terbang lima kali dalam seminggu: senin, Rabu, Jumat, Sabtu dan Minggu.

Pada tahun 2013, selain pelapisan overlay 1000x30 meter, juga dibangun dengan konstruksi baja.pembangunan terminal tersebut selesai pada tahun 2014. Dari sisi fisik ini saja, Bandara Matahora tak kala pamor dengan bandara Internasional. Terminal tersebut dioperasikan pada 17 Agustus 2015 saat Kabupaten Wakatobi menjadi tuan rumah penyelenggaraan Konferensi Internasional UCLG (United Cities Local Goverment Asia Pasifik). Organisasi ini adalah organisasi pemerintah daerah tingkat dunia yang diakui PBB yang berkantor di Spanyol dan memiliki komitmen untuk menjaga dan melindungi kelestarian lingkungan secara berkelanjutan. Hal tersebut tercapai karena adanya Bandara Matahora.

Bukan hanya hal tersebut di atas, sebelum hadirnya Bandara Matahora, penerbangan yang beroperasi di Sulawesi Tenggara Hanya Bandara Halu Oleo Kendari (sebelumnya bernama Wolter Monginsidi). Namun, setelah hadirnya Bandara Matahora, Bandara Betoambari di bau-bau hidup. Diikuti oleh Bandara Sangia Ni Bandera di Kolaka, Bandara Sugimanuru di Muna yang juga turut mengoperasikan pesawat jenis dornier yang sama. Hal tersebut bermakna bahwa, Bandara Matahora yang dicetuskan oleh Bupati Wakatobi Ir. Hugua yang mulanya di kritik habis-habisan oleh masyarakat, akhirnya menghidupkan dan menginspirasi bandara di Daerah-daerah lain yang ada di Sulawesi Tenggara.

Sejak berdirinya Bandara Matahora ini, perkembangan perekonomian daerah Kabupaten Wakatobi meningkat dengan begitu pesat terutama di Desa Sousu sebagai lokasi pembangunan Bandara matahora. Dalam perkembangannya, Bandara Matahora mengalami perkembangan yang signifikan. Dengan adanya Bandara Matahora, perkembangan perekonomian masyarakat di Pulau Wangi-Wangi khususnya di Desa Sousu mengalami perkembangan yang begitu pesat. Sebelum adanya Bandara Matahora, Desa Sousu ini adalah Desa yang tertinggal di Pulau Wangi-Wangi disamping itu jarak ke pasar dan Ibu Kota lumayan jauh. Dengan adanya Bandara Matahora, perekonomian masyarakat di Desa Sousu berkembang, salah satu fakta yang boisa dilihat adalah masyarakat di Desa Sousu sudah 100\% memiliki kendaraan baik kendaraan roda dua dan kendaraan roda empat

Disamping itu, Hal tersebut terlihat peningkatan trafik penumpang di bandara tersebut dimana pada tahun 2013, tercatat sebanyak 11.150 penumpang tiba dan 11.867 penumpang berangkat per tahun. Adapun di tahun 2015, trafik penumpang meningkat menjadi 19.100 penumpang tiba dan 20.081 penumpang berangkat per tahunnya. Hingga saat ini terus bertambah penumpang baik yang pergi maupun yang tiba di Bandara Matahora.

Berikut dapat dilihat perkembangan Bandara Matahora di Pulau Wangi-Wangi Kabupaten Wakatobi dari tahun berdirinya hingga saat sekarang ini pada tabel di bawah ini:

Tabel.

Perkembangan Pembangunan Bandara Matahora tahun 2007-sekarang

\begin{tabular}{|c|c|c|}
\hline Tahun & Kegiatan pembangunan & Keterangan \\
\hline 2006 & Tahap Perencaan & $\begin{array}{l}\text { ditandai dengan peletakan batu pertama oleh } \\
\text { Gubernur Sultra Ali Mazi, SH }\end{array}$ \\
\hline 2007 & Pembangunan Tahap I & $\begin{array}{l}\text { Pembangunan landasan pacu (runway) } \\
\text { panjang } 1400 \text { meterdan terminal mini dengan } \\
\text { menggunakan anggaran dari APBD }\end{array}$ \\
\hline 2008 & Pembangunan PKPPK & $\begin{array}{l}\text { Pemadam kebakaran Bandara } \\
\text { menggunakan anggaran dari APBD }\end{array}$ \\
\hline \multirow[t]{3}{*}{$\begin{array}{l}2009- \\
2011\end{array}$} & Peresmian Bandara & $\begin{array}{l}\text { Pendaratan perdana pesawat Caravan Susi Air } \\
\text { jenis PK-VVJ yang berkapasitas } 12 \text { orang } \\
\text { penumpang dan Susi Air jenis PK-VVH serta } \\
\text { Helikopter Polda Sultra }\end{array}$ \\
\hline & $\begin{array}{l}\text { Pembukaan rute Bau-bau } \\
\text { Wakatobi } \quad(\mathrm{pp}) \quad \text { dan } \\
\text { Kendari Wakatobi }(\mathrm{pp})\end{array}$ & $\begin{array}{l}\text { Menggunakan pesawat jenis Caravan Susi Air } \\
\text { jenis PK-VVJ yang berkapasitas } 12 \text { orang } \\
\text { penumpang }\end{array}$ \\
\hline & Penambahan pesawat & Jenis Expres Air tipe PK TXO jumlah \\
\hline
\end{tabular}


E-ISSN: $2502-6674$

P-ISSN: 2502-6666

http://ojs.uho.ac.id/index.php/p_sejarah_uho

2012- Pembangunan Tahap II

2015

Pergantian maskapai dengan

Lion Air dan Wings Air

2016 Dibangunnya terminal dengan

konstruksi baja

2017 Penambahan maskapai Garuda kapasitas penumpang 25 orang penumpang

Jenis Merpati tipe PK MZA

Penambahan pelapisan overlay 1000 x 30

meter serta Uprond $103 \times 73$ meter total

keseluruhan landasan 2500 meter dan

dilengkapi dengan terminal penumpang

Jadwal terbang hingga $5 \mathrm{x}$ seminggu

diakibatkan penumpang yang semakin bertambah

Jenis Wings Air tipe ATR 72_500 dengan

kapasitas penumpang 87 orang

Menggunakan APBN

Pesawat Garuda Indonesia Jenis ATR 72_600

dengan kapasitas 97 orang penumpang

Sumber: Bandara Matahora Kabupaten Wakaktobi

Berdasarkan data di atas, perkembangan Bandara Matahora tiap tahunnya selalu meningkat dan terus-menerus. Hadirnya Bandara Matahora ini memicu pertumbuhan ekonomi, meningkatkan jumlah kunjungan wisata, memperlancar hubungan sosial politik daerah dan pusat, memungkinkan para peneliti dan ilmuan datang hal ini dapat dilihat dengan dibangunnya sekolah konservasi lingkungan Internasional, serta memicu lahirnya prestasi yang diterimaKabupaten Wakatobi. Salah satu prestasinya ialah dinobatkannya Kabupaten Wakatobi menjadi cagar biosfer bumi.

\section{PENUTUP}

Latar belakang perkembangan Bandara Matahora berawal dari pemikiran seorang pemimpin bernama Ir. Hugua yang merupakan Bupati Wakatobi, dalam visi misinya ingin membangun dan menjadikan Kabupaten Wakatobi menjadi daerah yang digemari oleh banyak orang dengan visi "Terwujudnya Surga Nyta Bawah Laut di Pusat Segitiga Karang Dunia" yang kemudian visi tersebut dilengkapi dengan misi sebagai berikut: (1). Medorong peningkatan dan pemerataan kesejahteraan masyarakat, (2). Meningkatkan pengelolaan dan pelestarian sumberdaya alam, (3). Meningkatkan kualitas dan daya dukung infrastruktur wilayah, (4). Meningkatkan kualitas pelayanan publik dan tata kelola pemerintahan, dan (5). Mengembangkan situasi yang kondusif bagi kehidupan masyarakat yang inofatif. Kendala yang dihadapi dalam pembangunan Bandara Matahora dapat dilihat dari pandangan masyarakat yang diwujudkan dalam bentuk respon dari masyarakat berkaitan dengan pembangunan Bandara Matahora serta kecenderungan rencana yang akan dilakukan pasca Bandara terbangun. Respon yang dimaksud adalah respon mengenai pembangunan Bandara Matahora. Dampak dibangunnya Bandara Matahora di Pulau Wangi-Wangi Kabupaten Wakatobi dapat dilihat dari dampak positif diantaranya adalah Terbukanya lapangan kerja bagi masyarakat yang tidak atau yang sedang menganggur di wilayah sekitaran Bandara Matahora terhusus adalah masyarakat yang ada di Desa Sousu, banyaknya wiasatawan yang masuk ke Wakatobi baik dalam maupun luar negeri hingga pertumbuhan ekonomi masyarakat yang ada di Wakatobi khususnya di Pulau Wangi-Wangi membaikdan dampak negatif diantaranya adalah Lahan pertanian warga sekitar Bandara Matahora berkurang, aspek keselamatan bagi warga yang tinggal di sekitar Bandara Matahora, bisa menimbulkan polusi dan kebisingan bagi masyarakat yang tinggal di sekitar daerah Bandara Matahora serta mengurangi pendapatan pengusaha transportasi laut terutama transportasi kecil yang dimiliki masyarakat lokal. Perkembangan pembangunan Bandara Matahora dari tahun ke tahun semakin bagus, dimana Bandara yang menjadi kebanggaan masyarakat tersebut digunakan dengan semaksimal mungkin dan pembangunan tambahan Bandara terus berkelanjutan hingga saat ini. Disamping itu, banyak wisatawan dalam dan luar negeri yang mengunakan Bandara Matahora tersebut sebagai alternatif yang memungkinkan perjalanan masyarakat bisa dijangkau dengan cepat. 
E-ISSN: $2502-6674$

P-ISSN: 2502-6666

http://ojs.uho.ac.id/index.php/p_sejarah_uho

\section{DAFTAR PUSTAKA}

Arman Ayu, (2). 2016. Bandara Matahora (Pintu Wakatobi Mencapai 10 Top Destinasi Pariwisata Indonesia). Jakarta: Gramedia

Arman, Ayu. (1). 2016. Rekam Jejak Pemimpin Karang Wakatobi. Jakarta: Gramedia

Hadara, Ali. 2017. Sejarah Wakatobi: Dari Pra Integrasi Hingga Kabupaten. Kendari: Sekar Langit.

Kamarsyah, Ridwan. 1996. Perencanaan Regional. Jakarta: Karunika.

Lairissa, R.Z . 1996. Kebudayaan dan Perkembangan Sejarah. Jakarta: Balai Pustaka.

Maelissas. 2007.Pentingnya Kajian Ilmu Sejarah dalam Meningkatkan Kualitas Sumber Daya Manusia dan Pembangunan Daerah Maluku. Jurnal Kapata Arkeologi Edisi Khusus Hlm 63.

Najemi, 1993. Sejarah Perekonomian Masyarakat. Bandung: Jasa Guna.

Sjamsuddin, Helius. 2007. Metodologi Sejarah. Jogyakarta: Ombak.

Widjaya, Albert. 1982. Budaya Politik dan Pembangunan Ekonomi. Jakarta: Gramedia. 